\title{
Effects of Insulin, Insulin-like Growth Factor-II, and Nerve Growth Factor on Neurite Formation and Survival in Cultured Sympathetic and Sensory Neurons
}

\author{
Esperanza Recio-Pinto, ${ }^{1}$ Matthew M. Rechler, ${ }^{\star}$ and Douglas N. Ishii $\dagger$ \\ *Laboratory of Biochemical Pharmacology, National Institute of Arthritis, Metabolism, and Digestive Diseases, \\ National Institutes of Health, Bethesda, Maryland 20205, and \\ tDepartment of Physiology and Biophysics, Colorado State University, Fort Collins, Colorado 80523
}

Insulin and the insulin-like growth factors (IGFs) may directly affect the development of the nervous system. NGF, IGF-II, and insulin's effects on neurite formation and neuronal survival were studied in peripheral ganglion cell cultures from chick embryos. Neurite outgrowth was enhanced in a dose-dependent manner by insulin and IGF-II in sympathetic cell cultures. The halfmaximally effective concentration, $\mathrm{ED}_{50}$, was about 0.4-0.6 $\mathrm{nM}$ for both polypeptides, and concentrations as low as 10 pм were active. However, in sensory neurons the $\mathrm{ED}_{30}$ for neurite outgrowth was about $30 \mathrm{~nm}$ for insulin and $0.1 \mathrm{~nm}$ for IGF-II, suggesting that these factors may have selective effects in different neuronal tissues. Neither serum nor the presence of nonneuronal cells was required for the response in sympathetic neurons. The specific anti-NGF antiserum inhibited the neurite outgrowth response to NGF but not to insulin nor IGF-II. Insulin and IGF-II additionally supported survival of sensory and sympathetic neurons; however, insulin was not as efficacious as NGF. The combination of high concentrations of NGF and insulin was no better than NGF alone in supporting sympathetic cell survival, or neurite outgrowth. This indicates that insulin acts on the same, or a subpopulation, of NGF-responsive neurons. These results support the hypothesis that insulin and its homologs belong to a broad family of neuritogenic polypeptides.

Other than NGF, few, if any, chemically well-defined and physiologically important factors are known to be capable of enhancing neurite outgrowth (Barde et al., 1983; Mobley et al., 1977). In the presence of neurotrophic factors, the role of the substrate in supporting neurite outgrowth has been shown for substances such as laminin (Baron-Van Evercooren et al., 1982; Manthorpe et al., 1983). The identification of new neuritogenic agents would advance the present understanding of the devclopment of the nervous system. We suggest that insulin and its homologs may belong to a broad family of neuritogenic polypeptides. Although it has been the traditional view that neurons are not target cells for insulin, the mounting evidence suggests that insulin acts on both the PNS and CNS. For example, in the PNS, insulin treatment of cultured sensory ganglia can increase uridine and leucine incorporation (Burnham et al., 1974; Levi-Montalcini, 1964). Neurite outgrowth is enhanced in sensory (Bothwell, 1982; Snyder and Kim, 1980) and parasym-

\footnotetext{
Received Oct. 11, 1984; revised Nov. 1, 1985; accepted Nov. 1, 1985.

We thank Gregory M. Ishii and Aaron T. Ishii for fine technical assistance in parts of this study. This work was supported by Grant R01 AM32841 from the National Institute of Arthritis, Diabetes, Digestive and Kidney Diseases.

Correspondence should be addressed to Dr. Ishii, Physiology and Biophysics Department, Colorado State University, Fort Collins, CO 80523.

' Present address: Department of Physiology and Anesthesiology, Cornell University Medical Center, 1300 York Ave., New York, NY 10021.

Copyright (C) 1986 Society for Neuroscience $0270-6474 / 86 / 051211-09 \$ 02.00 / 0$
}

pathetic (Collins and Dawson, 1983) neurons. With respect to the CNS, ornithine decarboxylase activity (Roger and Fellows, 1980), and uridine and thymidine uptake (Raizada et al., 1980) are increased. Glucose uptake is reported as increased (Phillip and Coxon, 1976) or unchanged (Goodner and Berrie, 1977). Furthermore, insulin binding sites have been detected in brain homogenates (Havrankova et al., 1978a; Pacold and Blackard, 1979) and plasma membrane fractions (Landau et al., 1983; Posner et al., 1974).

The observations cited above have not stimulated quite the same intense investigative effort as in the NGF field, perhaps because of the following reservations: (1) Supraphysiological insulin concentrations were studied, raising questions as to physiological relevance and the possibility that the effects were spurious, e.g., due to an active contaminant. (2) The increased incorporation of precurser molecules could be predominantly into the non-neuronal cells. (3) Insulin may not be acting directly on the neurons. For example, the activity of ganglion satellite cells can substantially influence neuronal survival (Burnham et al., 1972). NGF, in addition, can be produced by various nonneuronal cells (Murphy et al., 1977; Young et al., 1975). Therefore, insulin may only indirectly enhance neuronal survival and neurite formation through stimulation of satellite cells. (4) The function of brain binding sites is unsettled, partly because sites are present on both neurons and glia (Raizada et al., 1982). Glia comprise the large majority of brain cells. At issue also is the problem of how insulin can reach beyond the few privileged sites in brain, in the face of the blood-brain barrier. Consequently, a clear-cut demonstration that physiological concentrations of insulin can act directly on neurons could help overcome many of these reservations.

Recently, we found that concentrations as low as 10-100 pM of insulin and insulin-like growth factor-II (IGF-II) could enhance neurite outgrowth in the cloned human neuroblastoma SH-SY5Y cell line (Recio-Pinto and Ishii, 1984; Recio-Pinto et al., 1984). Non-neurons were clearly unnecessary for the response. The implication that insulin and its homologs have an important direct role in the nervous system is further supported by the observation that the gene coding for IGF-II is expressed in brain (Soares et al., 1985). IGF-II is closely related in structure to insulin (Rinderknecht and Humbel, 1978) and has overlapping activities (Rinderknecht and Humbel, 1976; Zapf et al., 1978). Moreover, somatomedin (D'Ercole et al., 1980) and insulinlike (Havrankova et al., 1978b) activities have been detected in brain. In this study, we have considered whether (1) insulin and IGF-II can enhance neurite formation and survival in sensory and sympathetic cultures; (2) physiological concentrations are active; and (3) the effects are directly on the neuronal cells. We report that physiological concentrations of insulin and IGF-II are directly neuritogenic and share certain other key 


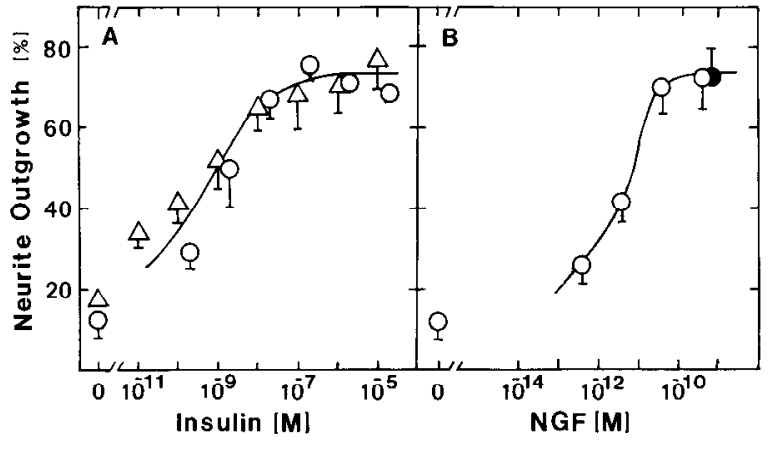

Figure 1. Effect of various concentrations of insulin and NGF on neurite outgrowth in sympathetic ganglion cells cultured in serum-containing medium. The cells were cultured for $1 \mathrm{~d}$ in the $\mathrm{L}-15$ plating medium wtih $10 \%$ fetal calf serum and the indicated concentrations of insulin or NGF. Neurite outgrowth was scored. Two separate experiments are shown: triangles, 12-d-old chick embryos; circles, 13-d-old embryos. The filled circle shows the effect of NGF together with $1 \mu \mathrm{M}$ insulin. The values are means \pm SEM; $n=4$ replicate cultures.

properties with NGF, a neurotrophic agent whose influence on the development of the sensory and sympathetic nervous system is well documented (Levi-Montalcini and Angeletti, 1968; Mobley et al., 1977).

\section{Materials and Methods}

\section{Materials}

Pork pancreatic insulin $(24 \mathrm{U} / \mathrm{mg}$ ) was purchased from Sigma Chemical Co. (St. Louis). It was dissolved in $0.01 \mathrm{~N} \mathrm{HCl}$ and stored at $-20^{\circ} \mathrm{C}$. IGF-II is also known as rat liver cell multiplication-stimulating activity (Acquaviva et al., 1982). The particular IGF-II preparation used is designated MSA-III-2, which is 7100 in molecular weight and has been purified to homogeneity (Moses et al., 1980). The beta subunit of NGF was prepared from male mouse saliva (Burton et al., 1978). Its purity, confirmed by the presence of a single band on gel electrophoresis, and biological potency are described elsewhere (Ishii, 1978). The anti-NGF antiserum was prepared by injecting the toe pads of 6- to 8-week-old female New Zealand albino rabbits with $2 \mathrm{mg}$ of the purified beta NGF in the presence of complete Freund's adjuvant. The antiserum gave a single precipitin band against purified NGF and against submaxillary gland $105,000 \times g$ supernatant on Ouchterlony plates and immunoelectrophoresis. The preparation and properties of the antiserum are more completely described elsewhere (Ishii and Shooter, 1975). The antiserum was twice precipitated at $4{ }^{\circ} \mathrm{C}$ with $45 \%$ saturated ammonium sulfate that had been neutralized with ammonium hydroxide. The resulting crude gamma globulin fraction was dialyzed against $0.15 \mathrm{M} \mathrm{NaCl}$ and $10 \mathrm{mM} \mathrm{KH}_{2} \mathrm{PO}_{4}, \mathrm{pH} 7$, and stored frozen in aliquots at $-20^{\circ} \mathrm{C}$. Methocel (65HG, $4000 \mathrm{cp}$, Fuka AG) was purchased from Tridon Chemical Co. (Hauppauge, NY).

\section{Ganglion cell cultures}

The excised ganglia were washed in Roswell Park Memorial Institute Culture Medium 1640 (RPMI 1640) and incubated for 20 min at $37^{\circ} \mathrm{C}$ in Hanks' salt solution containing $31 \mathrm{U} / \mathrm{ml}$ trypsin for sympathetic and $6.2 \mathrm{U} / \mathrm{ml}$ for dorsal root ganglia. The enzyme solution was discarded. The ganglia were washed $3 \times$ in RPMI 1640 medium with $10 \%$ serum, resuspended in medium of the same composition, and dissociated by trituration through a Pasteur pipette. Debris was removed by permitting undissociated fragments to settle for $2 \mathrm{~min}$, and the cells were collected by centrifugation at $600 \times g$ for $5 \mathrm{~min}$. The cell pellet was resuspended in the appropriate plating medium described below, $50-85,000$ cells were seeded in $1.0 \mathrm{ml}$ onto protamine sulfate-coated $17.6 \mathrm{~mm}$ multiwell plates, and incubated at $37^{\circ} \mathrm{C}$ in humidified air under various conditions. The cultures were fed on alternate days. The tissue culture plates were prepared in advance by treatment for at least $2 \mathrm{hr}$ in $1 \mathrm{mg} / \mathrm{ml}$ protamine sulfate, followed by washing $3 \times$ with RPMI 1640 medium.

\section{Sympathetic ganglion cell cultures}

Several methods were evaluated, and the following was the most satisfactory. Lumbar sympathetic ganglia from 12- to 13-d-old white leg- horn chick embryos were dissociated and cells cultured in the plating medium described by Mains and Patterson (1973), which was modified in the following way. The L-15 plating medium contained their vitamin $\mathrm{mix}, 3 \mathrm{mg} / \mathrm{ml} \mathrm{BSA}$, and $0.1 \mathrm{mg} / \mathrm{ml}$ transferrin, but NGF was omitted. Fetal calf serum ( 5 or $10 \%$ ) was present only where indicated.

Dorsal root ganglion cell cultures

Dorsal root ganglia from 10-d-old chick embryos were dissociated, and the cells were cultured in the plating medium comprised of the RPMI 1640 medium supplemented with the N2 hormone mixture described by Bottenstein and Sato (1979), but without insulin. Other conditions are described in the legends.

\section{Cytosine arabinofuranoside treatment of cultures}

In some experiments with sympathetic cells, cytosine arabinofuranoside (ara-C) was used to inhibit the growth of non-neuronal cells (Wood and Bunge, 1975). The cells were incubated for $2 \mathrm{~d}$ in the plating medium which contained, in addition, $12 \%$ fetal calf serum and $20 \mathrm{ng} / \mathrm{ml} \mathrm{NGF}$ or insulin as described. Cytosine arabinofuranoside $(2.5 \mu \mathrm{g} / \mathrm{ml})$ was added and the incubations continued for 3 more d, at which time very few non-neuronal cells were visible. The cultures were washed and the cells were incubated further as described.

\section{Neurite outgrowth and neuronal survival}

The characteristic morphology of chick sympathetic (Chamley et al., 1972; Mains and Patterson, 1973) and sensory (Scott et al., 1969) ganglion cell cultures have been described. For example, the capsule, neurilemma, and fibroblast cells are $7-10 \mu \mathrm{m}$ in diameter and assume a fibroblast-like shape after $1 \mathrm{~d}$ in culture (Scott et al., 1969). But the sensory neurons are phase-bright, about $30 \mu \mathrm{m}$ in diameter, and remain round in shape. Sympathetic neurons are more variable in size. For our purposes, the spherical cells that were bright and had a clear nucleus under modulation contrast were scored as neurons. The scoring of neurites followed a procedure similar to that used previously (Sonnenfeld and Ishii, 1982; Spinelli et al., 1982). Briefly, the percentage of neurons bearing neurites was determined by replicate counts on more than 100 neurons in several randomly chosen fields under low-power modulation contrast microscopy. A field was $1.2 \%$ of the total culture area. Where survival was poor, additional fields were counted so that at least 100 neurons were always scored. Only neurons with processes equal to or longer than $40 \mu \mathrm{m}$ were scored as positive. Neurons with multiple processes were scored only once. Neurites could generally be identified by the presence of growth cones. To score survival, the neurons found in four 100X fields in predetermined locations along the north-south and east-west axes were counted in each of four replicate cultures. Values are means and SEM.

\section{Statistical analysis}

Analysis of variance and the Bonferroni multiple $t$ test (Dunn and Clark, 1974) were used to compare experimental groups. Data expressed as percentages were transformed to arcsine values prior to statistical analysis.

\section{Results}

\section{Effects of insulin and NGF on neurite outgrowth in sympathetic cell cultures}

In serum-containing medium, the maximum proportion of neurite-bearing cells is observed within a day, although the neurites do continue to elongate. The sympathetic ganglion cells were cultured in the presence of various concentrations of insulin or NGF for $1 \mathrm{~d}$; then the proportion of neurons with neurites was scorcd. The ncurite outgrowth responsc to insulin from two separate experiments is shown in Figure $1 A$. The $\mathrm{ED}_{50}$, the concentration at which the half-maximal neurite outgrowth response is obtained, was about $0.4 \mathrm{nM}$ for each experiment. The contribution of insulin from the serum, about 4 pM, was negligible and therefore not included in the concentrations shown in Figure $1 A$. Note that the same sensitivity is observed in serum-free medium (Fig. 2). The data obtained from cultures with and without serum were pooled, and the $\mathrm{ED}_{50}$ was about $0.57 \pm 0.19 \mathrm{nM}$ (mean $\pm \mathrm{SEM}, n=3$ experiments). An exten- 
sive network of fasciculated neurites, which covered the entire culture surface, was observed after several weeks.

In the same experiment indicated by the circles in Figure $1 \mathrm{~A}$, the response to NGF was studied (Fig. $1 B$ ). The $\mathrm{ED}_{50}$ was about $0.1 \mathrm{ng} / \mathrm{ml}(4 \mathrm{pM})$, a value close to that previously reported (Ishii, 1978). The maximum response was about $77 \%$, similar to the value obtained by Varon and Raiborn (1972). Two observations suggest that insulin may be acting on the same or a subpopulation of NGF-responsive neurons. First, the same proportion of sympathetic neurons was responsive to insulin (Fig. $1 A$ ) and to NGF (Fig. $1 B$ ). Second, the combination of high concentrations of insulin and NGF had no greater effect than either factor alone (Fig. 1B). The experiments on survival described below provide additional strong support for this hypothesis.

The culture medium contained transferrin, which can increase neuronal survival (Bottenstein, 1980). In the absence of transferrin, the sensitivity to insulin, based on the $\mathrm{ED}_{50}$, fell to about $20 \mathrm{~nm}$ from $0.4 \mathrm{~nm}$. The maximum neurite outgrowth response varied somewhat from experiment to experiment.

\section{Effect of IGF-II on neurite outgrowth in sympathetic cell cultures}

The effect of various concentrations of IGF-II and insulin on neuritc outgrowth in cclls cultured in serum-free medium is shown in Figure 2. The slower rate and apparent lower maximum in the neurite outgrowth response to insulin under the serum-free condition compared to that in serum-containing medium is due, perhaps, to a slower metabolic rate under the former condition. Insulin and IGF-II concentrations as low as $10 \mathrm{pM}$ were effective. The $\mathrm{ED}_{50}$ for neurite outgrowth was about $0.4 \mathrm{~nm}$ for both polypeptides. The IGF-II dose-response curve was about the same when additionally studied in serum-containing cultures (not shown). Evidently, the other components in serum are not required for the neurite outgrowth response to insulin and IGF-II. The level of spontaneous neurite outgrowth was lower in serum-free (Fig. 2) than in serum-containing medium (Fig. 1), which indicates that the endogenous insulin, IGFII, NGF, and other neuritogenic factors ordinarily present in serum are active. Spontaneous neurite outgrowth is sensitive to serum factors in SH-SY5Y cells also (Recio-Pinto et al., 1984).

\section{Effect of anti-NGF antiserum on the neurite outgrowth response to insulin, $I G F-I I$, and NGF in sympathetic cell cultures}

Studies were conducted to determine whether NGF might be present as a contaminant in preparations of insulin and IGFII. The effect of the specific anti-NGF antiserum (Ishii and Shooter, 1975) on the neurite outgrowth response was examined. Insulin, IGF-II, and NGF increased neurite outgrowth (Table 1). The anti-NGF antiserum inhibited the neurite outgrowth response to NGF but not to insulin or IGF-II. The amount of anti-NGF antiserum used was sufficient to neutralize the insulin preparation, even were all of it NGF. The other studies that show that the effects of insulin and IGF-II are distinct from that of NGF are discussed below.

\section{Effect of insulin, IGF-II, and NGF on the morphology of cultured sympathetic cells}

Sympathetic cells were cultured in serum-containing medium supplemented with insulin, NGF, or both factors for $2 \mathrm{~d}$. The morphology of the cultures is shown in Figure 3. In the absence of treatment, very few neurites were observed, and the number of neurons was greatly diminished (Fig. $3 A$ ). However, with insulin and NGF treatment, many neurites and more neurons were seen (Fig. 3, B, C). After a few weeks, all cultures showed a dense, interconnecting network of neuronal processes. A remarkable difference in the morphology between insulin- and NGF-treated cultures was not noticed. In other studies, the

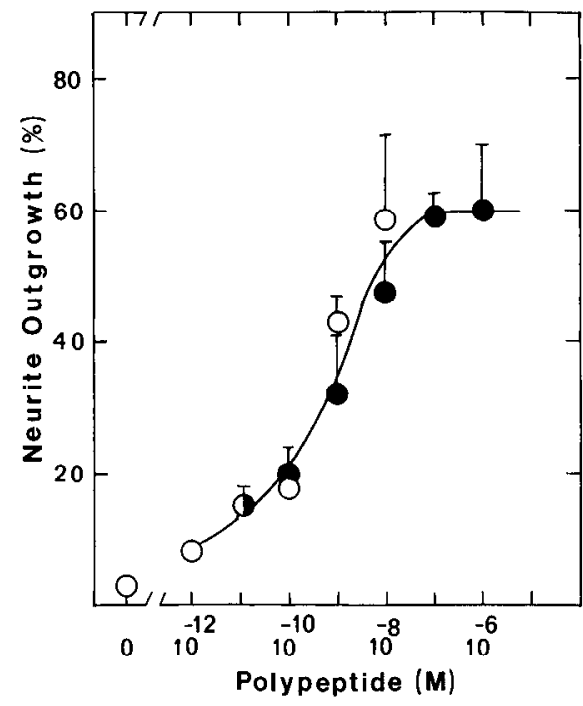

Figure 2. Effect of various concentrations of IGF-II and insulin on neurite outgrowth in sympathetic ganglion cells cultured in serum-free medium. The cells were cultured for $3.5 \mathrm{~d}$ in the L-15 plating medium without serum and with the indicated concentrations of IGF-II $(O)$ or insulin (@). Neurite outgrowth was scored. The values are means \pm SEM; $n=3$ replicate cultures.

morphology of IGF-II-treated cultures could not be distinguished from that of insulin-treated cultures (not shown).

\section{Effect of insulin and IGF-II on neurite outgrowth in sensory cell cultures}

Dorsal root ganglion cells were cultured in serum-free medium with various concentrations of insulin and IGF-II; neurite outgrowth was scored after $3.5 \mathrm{~d}$ (Fig. 4). IGF-II concentrations as low as a few picomoles were active. The $\mathrm{ED}_{50}$ for neurite outgrowth was about $30 \mathrm{~nm}$ for insulin and $0.1 \mathrm{nM}$ for IGF-II. These results show that physiological concentrations of IGF-II can enhance neurite outgrowth in sensory as well as in sympathetic neurons. Moreover, there appears to be a tissue-dependent difference in sensitivity to these factors. Insulin and IGF-II are equally potent in sympathetic neurons (Fig. 2), but insulin is about 300 -fold less potent than IGF-II in sensory

\section{Table 1. Effect of the anti-NGF antiserum on neurite outgrowth mediated by insulin, IGF-II, and NGF in embryonic chick sympathetic neurons}

\begin{tabular}{ll} 
Additions & $\begin{array}{l}\text { Neurite outgrowth } \\
(\%)\end{array}$ \\
\hline None & $17.8 \pm 1.8$ \\
Anti-NGF, $10 \mu \mathrm{l} / \mathrm{ml}$ & $29.8 \pm 4.8^{a}$ \\
$\mathrm{NGF}, 1 \mathrm{ng} / \mathrm{ml}$ & $82.7 \pm 5.7^{b}$ \\
$\mathrm{NGF}, 1 \mathrm{ng} / \mathrm{ml} \mathrm{plus}$ anti-NGF, $10 \mu \mathrm{l} / \mathrm{ml}$ & $17.6 \pm 7.0^{c}$ \\
Insulin, $10 \mathrm{nM}$ & $65.1 \pm 5.6^{b}$ \\
Insulin, $10 \mathrm{nM}$ plus anti-NGF, $10 \mu \mathrm{l} / \mathrm{ml}$ & $67.0 \pm 7.3^{a . b}$ \\
IGF-II, $1 \mathrm{nM}$ & $80.1 \pm 6.4^{b}$ \\
IGF-II, $1 \mathrm{~nm}$ plus anti-NGF, $10 \mu \mathrm{l} / \mathrm{ml}$ & $82.4 \pm 4.8^{a . b}$
\end{tabular}

Sympathetic ganglion cells from 12-d-old embryonic chicks were cultured for 1 $\mathrm{d}$ in medium containing serum and the indicated additions. The cultures were scored for the proportion of neurite-bearing cells. Values are means $\pm \operatorname{SEM} ; n=$ 4 replicate cultures.

- Not significantly different from group immediately preceding.

${ }^{b} p<0.01$ between group and untreated cultures.

${ }^{c} p<0.01$ between group and group immediately preceding. 

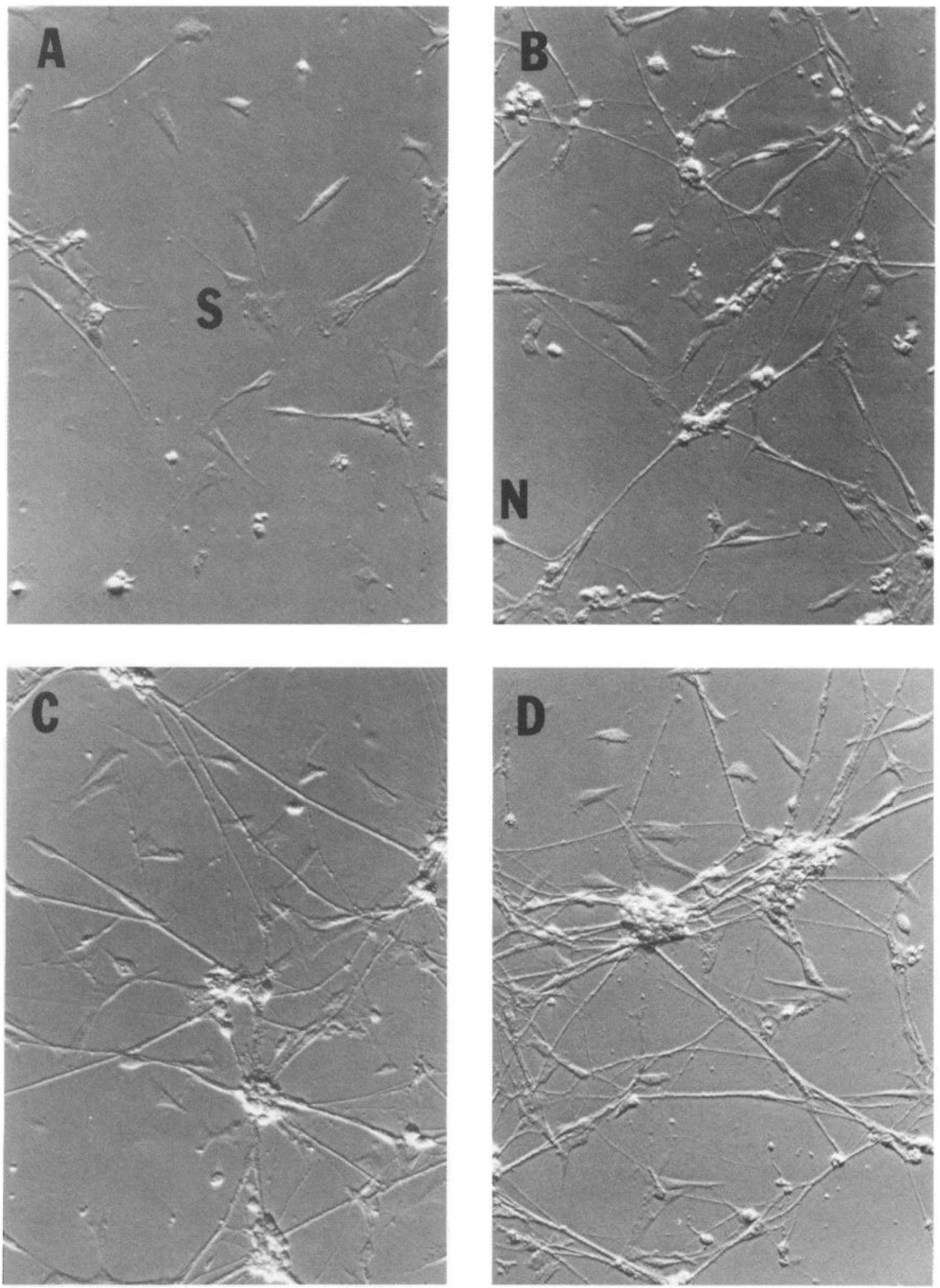

Figure 3. Morphology of sympathetic cells cultured in the L-15 plating medium with $10 \%$ serum, insulin, and NGF for 2 d: $A$, untreated; $B$, plus $1 \mu \mathrm{M}$ insulin; $C$, plus $0.4 \mathrm{nM}$ NGF; and $D$, plus $1 \mu \mathrm{M}$ insulin and $0.4 \mathrm{nM}$ NGF. Abbreviations: $N$, neuron; $S$, non-neuron. Modulation contrast, $\times 260$.

neurons (Fig. 4). This appears to be due to a lower sensitivity to insulin in the sensory neurons from 10 -d-old embryos. Like the sympathetic neurons, sensory neurons did not require serum for the response to insulin or IGF-II.
Effect of insulin, IGF-II, and NGF on the survival of embryonic neurons

NGF is an important requirement for the survival of sensory and sympathetic neurons (for review, see Mobley et al., 1977). 


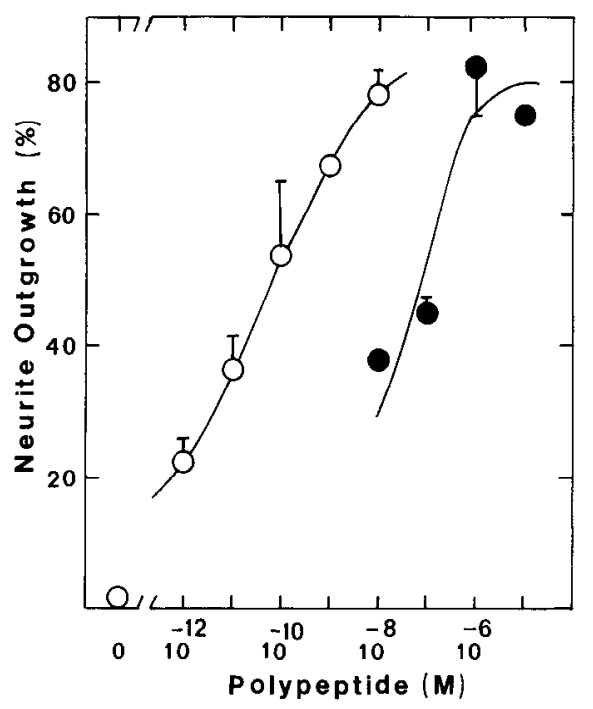

Figure 4. Effect of various concentrations of IGF-II and insulin on neurite outgrowth in dorsal root ganglion cells. Sensory cell cultures from 10-d-old embryonic chicks were cultured in the RPMI 1640 plating medium without serum and with various concentrations of IGF-II (O) and insulin (๑). Neurite outgrowth was scored after $3.5 \mathrm{~d}$. The values are means \pm range; $n=2$ replicate cultures (100-150 cells scored per culture).

The effect of various concentrations of insulin and NGF on the number of surviving sympathetic neurons is shown in Figure 5. We can estimate the number of surviving neurons. The maximal survival response to NGF, based on Figure $5 B$, is approximately (700 neurons/area of four fields) $\times$ (total area of culture) $=$ 14,600 neurons. The number of total cells seeded was 82,000 . About half of the seeded cells at this stage of development are neurons (Varon and Raiborn, 1972). Therefore, we calculate a plating cfficicncy of $36 \%$ for the neurons. This value may be compared with the $25 \%$ observed by Varon and Raiborn (1972) under their culture conditions. NGF appeared to be more efficacious than insulin in supporting neuronal survival. If NGF and insulin were acting on separate neuronal cell populations, treatment with both factors should result in an additive effect on survival. However, the combination of high concentrations of insulin and NGF had no greater effect than NGF alone (Fig. $5 B$ ). The interesting implications will be discussed.

These results were obtained as part of the same experiment shown in Figure 1 (indicated by the circles), and the two effects may be compared. The dose-response curves for the effects of insulin on neurite outgrowth (Fig. 1 $A$ ) and survival (Fig. 5A) appear to share the same sensitivity. The same seems to be the case for NGF (Figs. $1 B, 5 B$ ). Survival and neurite outgrowth, then, are functions that share the same dose-response curve. However, these functions need not be linked. Consider that neurite outgrowth was scored at $1 \mathrm{~d}$ (Fig. $1 A$ ) and survival at $2.5 \mathrm{~d}$ (Fig. 5). Neurons, of course, do not immediately die in the absence of these factors. It is, then, not surprising that $100 \%$ of surviving neurons do not have neurites, particularly early after seeding. In fact, Varon and Raiborn (1972) have observed separate time courses in the survival and neurite outgrowth responses to NGF in sympathetic neurons. Survival and neurite outgrowth are clearly distinct responses also in neuroblastoma cells (Sonnenfeld and Ishii, 1982).

Attempts were not made to quantify the survival effect of IGF-II, but it was visually apparent that IGF-II was a survival factor too. Furthermore, insulin and IGF-II enhanced the survival of sensory neurons.

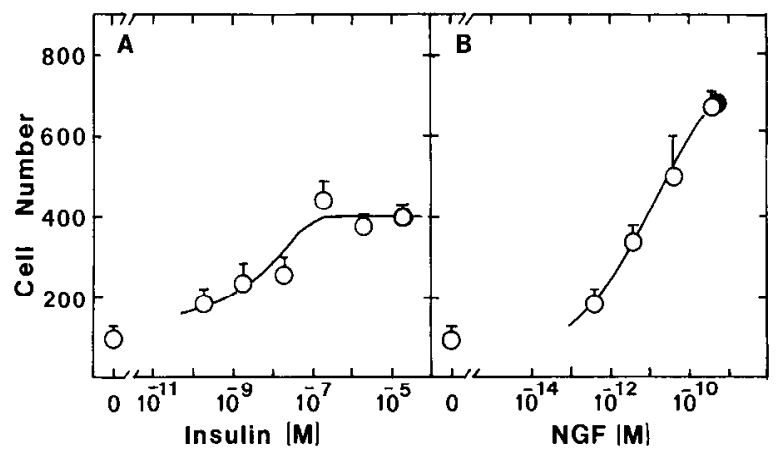

Figure 5. Effect of various concentrations of insulin and NGF on survival in cultured sympathetic neurons. The experiment is a continuation of that described in Figure 1 and the conditions and the symbols are the same, except that at $2.5 \mathrm{~d}$ the number of surviving neurons in four predetermined fields in each culture was counted $(82,000$ cells were plated). A field is $1.2 \%$ of the total culture area. Values arc mcans \pm $\mathrm{SEM} ; n=4$ replicate cultures.

\section{Effect of insulin on neurite outgrowth in sympathetic cultures following treatment with Methocel or cytosine arabinoside}

It was possible that insulin was acting indirectly through effects on non-neurons. Therefore, sympathetic ganglion cells were cultured under two separate conditions known to inhibit the proliferation of non-neurons. Mains and Patterson (1973) have shown that sympathetic neurons may be cultured free of nonneuronal cells by deletion of bicarbonate and addition of Methocel. Our culture medium was a slight modification. Protamine sulfate was used instead of collagen as the substrate, and 0.1 $\mathrm{mg} / \mathrm{ml}$ transferrin and $10 \%$ fetal calf serum were included. Fetal calf serum is toxic to ral (Mains and Patterson, 1973) but not to chick sympathetic neurons. The morphology of chick sympathetic ganglion cells cultured for $2 \mathrm{~d}$ in this medium is shown in Figure 6. The non-neurons ordinarily present (Fig. 3) are virtually absent. The survival of neurons was poor, and few neurites were observed in control cultures (Fig. 6 $A$ ). Survival and neurite outgrowth were enhanced by insulin, NGF, and their combination under conditions in which the non-neuronal cells were virtually absent (Fig. 6, $B-D$ ).

Cytosine arabinofuranoside (ara-C) is toxic to proliferating non-neuronal ganglion cells but not to the essentially quiescent neuronal cells. After scoring of the experiment shown by the triangles in Figure $1 A$, the cultures were treated with $2.5 \mu \mathrm{g} / \mathrm{ml}$ ara-C for $4 \mathrm{~d}$. Thereafter, the cultures were washed, and the incubations were continued in the same concentrations of insulin as beforc. Even after 3 weeks, non-neuronal cells were absent, whereas a continuous monolayer of mesenchyme cells was ordinarily observed in cultures not treated with ara-C. Nevertheless, the neurites became very long in the insulin-treated cultures, forming networks like those following long-term treatment with NGF.

These results show that non-neuronal cells are neither required for the effects of insulin on neurite outgrowth nor survival in sympathetic neurons.

\section{Discussion}

Our results show that physiological concentrations of insulin and IGF-II can enhance survival and neurite formation in sympathetic and sensory neurons. These effects are observed with insulin even in sympathetic cell cultures that are essentially devoid of non-neuronal cells. It is evident then that insulin and IGF-II do act directly on neurons. We shall now discuss the implications of the effects on neuronal survival, the neuritogenic role of these factors in different cell types, the validity of these findings, and the mechanism of action. 

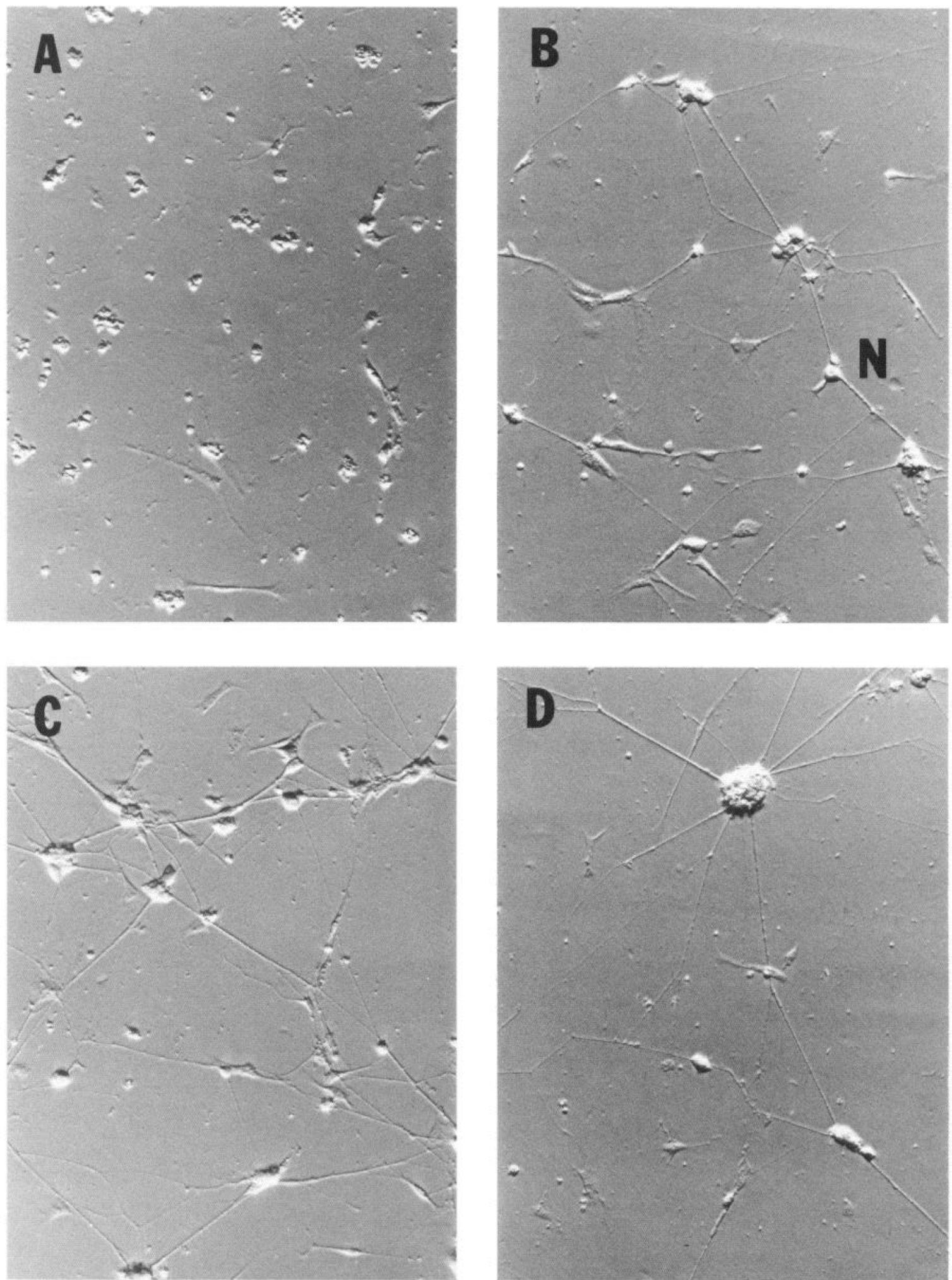

Figure 6. Effect of Methocel on neurite outgrowth and the morphology of sympathetic cells cultured in medium with insulin and NGF. Cells were cultured for $2 \mathrm{~d}$ in the L-15 plating medium containing $7 \mathrm{mg} / \mathrm{ml}$ Methocel, $10 \%$ serum, and the indicated additions: $A$, no additions; $B$, plus $2 \mu \mathrm{M}$ insulin; $C$, plus $0.4 \mathrm{~nm}$ NGF; $D$, plus $2 \mu \mathrm{m}$ insulin and $0.4 \mathrm{~nm}$ NGF. Figure label: $N$, neuron. Modulation contrast, $\times 260$. The neurite outgrowth in a separate experiment, under these conditions in which the non-neuronal cells were virtually eliminated, was as follows: no additions, $11.2 \pm$ $1.5 \%$; plus insulin, $42.8 \pm 6.0 \%$; plus NGF, $58.0 \pm 6.0 \%$; plus insulin and NGF, $66.8 \pm 7.2$. The values are means \pm SEM; $n=4$ replicate cultures.

Survival plays an important role in sculpting the nervous system during development (reviewed in Mobley et al., 1977). For example, the hyperplasia of sympathetic ganglia that follows treatment with NGF is largely the result of a decrease in the preprogrammed death of overproduced neuronal cells. During synaptogenesis it appears that there is competition among growing neurites for the target cell source of NGF, which undergoes retrograde axonal transport and modulates neuronal cell func- 
Table 2. Half-maximally effective concentrations $\left(\mathrm{ED}_{50}\right)$ for neurite outgrowth stimulated by insulin and IGF-II in different types of cells

\begin{tabular}{|c|c|c|c|}
\hline \multirow[b]{2}{*}{ Type of cell } & \multicolumn{2}{|c|}{$\begin{array}{l}\text { Neurite outgrowth } \\
\left(E_{50}\right)\end{array}$} & \multirow[b]{2}{*}{ Reference } \\
\hline & $\begin{array}{l}\text { Insulin } \\
(\mathrm{nM})\end{array}$ & $\begin{array}{l}\text { IGF-II } \\
\text { (nM) }\end{array}$ & \\
\hline Chick parasympathetic ciliary neurons & 160 & & Collins and Dawson, 1983 \\
\hline \multirow{2}{*}{ Chick sensory neurons } & 50 & 4 & Bothwell, 1982 \\
\hline & 30 & 0.1 & This study \\
\hline Chick sympathetic neurons & 0.4 & 0.4 & This study \\
\hline \multirow[t]{2}{*}{ Human neuroblastoma cells } & 4 & 0.5 & Recio-Pinto and Ishii, 1984 \\
\hline & $0.1^{a}$ & & Recio-Pinto and Ishii, 1984 \\
\hline
\end{tabular}

${ }^{a}$ Studied in the presence of the protease inhibitor bacitracin.

tion. It is probable that other factors, in addition to NGF, are important to survival. In the absence of a high concentration of transferrin, NGF alone is insufficient to support survival of sympathetic and sensory neurons and serum is generally included in cultures. It is, therefore, noteworthy that low concentrations of insulin and IGF-II can enhance survival (Fig. 5). I his is a direct effect. Insulin supports survival of about half as many neurons as NGF, and appears less efficacious. The combination of optimum concentrations of both factors results in no greater survival than with NGF alone. This suggests either that insulin acts on a subpopulation of the NGF-responsive cells or that insulin is less efficacious and can support survival of only a fraction of all of the NGF-responsive neurons. It is also possible that there is no difference in the efficacy of insulin and NGF in supporting the survival of attached neurons. Cultures initiated under NGF-treatment do not appear to suffer a substantial loss of neurons following subsequent washout of NGF and continued treatment with insulin alone. This suggests that insulin may not be as active as NGF in supporting neurons during their critical transition into culture, possibly on events such as attachment. Whatever the mechanism, the poorer survival with insulin poses a problem for the experimentalist. The improved survival of neurons in transferrin-supplemented cultures probably explains, in large measure, why we have been able to observe these effects at physiological rather than the supraphysiological concentrations studied by others.

Neurite outgrowth is potentially a secondary consequence of the effects of insulin on survival (Bothwell, 1982; Snyder and Kim, 1980). This view appears to be supported by the observation that the dose-response curves for neurite outgrowth (Fig. $1 A$ ) and survival (Fig. $5 A$ ) are very similar. The neurons are exposed to NGF and other factors prior to explantation. Survival enhanced by insulin may simply permit a transient expression in culture of the stimulation obtained in vivo. We believe this to be an implausible explanation for insulin's activity. Insulin and IGF-II can support neurites in cells cultured for as long as 3 weeks, and it is very unlikely that neuritogenic factors active prior to cultivation have as long a residual effect. Survival and neurite outgrowth need not be linked, as already shown for NGF in neurons (Campenot, 1977; Gundersen and Barrett, 1980; Menesini Chen et al., 1978). They are also unlinked in the response of human neuroblastoma cells to NGF (Sonnenfeld and Ishii, 1982), insulin (Recio-Pinto and Ishii, 1984), and tumor promoters (Spinelli et al., 1982). However, additional studies are necessary to demonstrate directly that these responses are unlinked when induced by insulin and IGF-II in sympathetic and dorsal root ganglia cells.

There can be substantial cross-occupancy of insulin and IGF receptors (Rechler et al., 1983). Insulin's low potency suggests that it acts through the IGF sites in both sensory and parasympathetic neurons. The half-maximal effective concentrations that stimulate neurite formation in different types of cells are shown in Table 2 . Insulin and IGF-II are equally potent in sympathetic neurons (Fig. 2). However, insulin is 300 -fold less potent than IGF-II in sensory neurons (Fig. 4). The selective response indicates that insulin may play a role subordinate to that of the IGFs in 10-d-old embryonic sensory neurons. Our $E_{50}$ value for insulin is similar to that reported by Bothwell (1982). The small difference may be due to the presence of transferrin in our cultures. The larger difference in $\mathrm{ED}_{30}$ values for IGF-II is probably the result, at least in part, of Bothwell's use of commercial IGF-II, which we too have found to be variable in potency from lot to lot. High concentrations of insulin are also required to stimulate neurite formation in parasympathetic neurons (Collins and Dawson, 1983). As with the sensory neurons, insulin may not be the preferred ligand.

The validity of these findings requires some comment. These results are not attributable to NGF as a contaminant in insulin and IGF-II preparations. The anti-NGF antiserum does not inhibit the response to insulin or IGF-II (Table 1). On the other hand, the anti-insulin antiserum does inhibit neurite outgrowth stimulated by insulin, but not NGF, in SH-SY5Y cells (RecioPinto et al., 1984). Preparations of insulin and IGF-II do not compete for the binding of ${ }^{125}$ I-NGF to its specific high-affinity receptors (Recio-Pinto and Ishii, 1984). Purified human insulin, prepared by bacterial synthesis of $A$ and $B$ chains, and combination of the chains, is as potent as porcine and bovine insulins in enhancing neurite outgrowth in human neuroblastoma cells. It is highly unlikely that synthetic human insulin and insulin extracted from tissue sources have equal amounts of the same active contaminant. Moreover, there is a qualitative difference in the activity of insulin and NGF preparations. Unlike NGF, insulin by itself cannot enhance neurite outgrowth in cultured pheochromocytoma PC12 cells (Recio-Pinto et al., 1984).

It is difficult to study the mechanism of IGF-II and insulindependent neurite formation in sensory and sympathetic neurons, because these factors also support neuronal survival. Dying untrcated cultures do not provide adequate experimental controls. The human neuroblastoma SH-SY $5 Y$ cell is an alternative model for the study of neuritogenesis (Ishii et al., 1985), useful partly because it does not require these factors for survival (Sonnenfeld and Ishii, 1982). Most likely, neuroblastoma is derived from sympathetic cells, and possibly from sensory cells. SIISY5Y cells contain tyrosine hydroxylase and dopamine betahydroxylase (Biedler et al., 1978), indicating their sympathetic phenotype. Insulin and IGF-II directly and reversibly enhance neurite formation in SH-SY5Y cells (Recio-Pinto and Ishii, 1984). The $E D_{50}$ values in cells cultured with and without the protease inhibitor bacitracin are shown in Table 2. Insulin and IGF-II have similar potencies in human SH-SY 5Y and chick sympathetic cells. Serum is required in neither of these kinds of cells for the neurite outgrowth response. Microtubules are 
important cytoskeletal elements of axons. There is a good correlation between insulin's capacity to increase tubulin mRNA levels and enhance neurite outgrowth in SH-SY5Y cells (Mill et al., 1985). IGF-II also stimulates an increase in tubulin transcript levels. Insulin increases ${ }^{3} \mathrm{H}$-leucine and ${ }^{3} \mathrm{H}$-uridine uptake (Recio-Pinto and Ishii, 1984). These increases, and neurite outgrowth, are inhibited by cycloheximide and actinomycin D, respectively. The effect of cycloheximide is reversible. These observations suggest that protein synthesis is important in insulin-stimulated neurite formation. NGF (Sonnenfeld and Ishii, 1982) and tumor promoters (Spinelli et al., 1982) are other significant factors that stimulate neurite formation in SH-SY5Y cells. It is unlikely that insulin is acting directly through the NGF or tumor-promoter receptors, for insulin does not inhibit tumor-promoter binding (Spinelli and Ishii, 1983), and neither insulin nor IGF-II inhibits NGF binding (Recio-Pinto and Ishii, 1984). Separate insulin and IGF receptors have been identified on these cells (unpublished observations).

The contents of this report, when taken together with the observations of others, support the reasonable hypothesis that insulin and IGF-II are members of a broad family of structurally related neuritogenic agents. These factors are but two of a series of structurally related polypeptides with overlapping actions (Rinderknecht and Humbel, 1976; Zapf et al., 1978). It seems likely that other members will be uncovered.

\section{References}

Acquaviva, A. M., C. B. Bruni, S. P. Nissley, and M. M. Rechler (1982) Cell-free synthesis of rat insulin-like growth factor II. Diabetes 31 : 656-658.

Barde, Y.-A., D. Edgar, and H. Thoenen (1983) New neurotrophic factors. Annu. Rev. Physiol. 45: 601-612.

Baron-Van Evercooren, A., H. K. Kleinman, S. Ohno, P. Marangos, J. P. Schwartz, and M. E. Dubois-Dalcq (1982) Nerve growth factor, laminin, and fibronectin promote neurite growth in human fetal sensory ganglia cultures. J. Neurosci. Res. 8: 179-193.

Biedler, J. L., S. R. Tarlov, M. Schachner, and L S. Freedman (1978) Multiple neurotransmitter synthesis by human neuroblastoma cell lines and clones. Cancer Res. 38: 3751-3757.

Bothwell, M. (1982) Insulin and somatomedin MSA promote nerve growth factor-independent neurite formation by cultured chick dorsal root ganglionic sensory neurons. J. Neurosci. Res. 8: 225-231.

Bottenstein, J. E. (1980) Serum-free culture of neuroblastoma cells. In Advances in Neuroblastoma Research, Audrey E. Evans, ed., pp. 161-170, Raven, New York.

Bottenstein, J. E., and G. H. Sato (1979) Growth of a rat neuroblastoma cell line in serum-free supplemented medium. Proc. Natl. Acad. Sci. USA 76: 514-517.

Burnham, P. A., C. Raiborn, and S. Varon (1972) Replacement of nerve growth factor by ganglionic non-neuronal cells for the survival in vitro of dissociated ganglionic neurons. Proc. Natl. Acad. Sci. USA 69: 3556-3560.

Burnham, P. A., J. A. Silva, and S. Varon (1974) Anabolic responses of embryonic dorsal root ganglia to nerve growth factor, insulin, concanavalin A or serum in vitro. J. Neurochem. 23: 689-695.

Burton, L. E., W. H. Wilson, and E. M. Shooter (1978) Nerve growth factor in mouse saliva: Rapid isolation procedures for and characterisation of $7 \mathrm{~S}$ nerve growth factor. J. Biol. Chem. 253: 7807-7812.

Campenot, R. B. (1977) Local control of neurite development by nerve growth factor. Proc. Natl. Acad. Sci. USA 74: 4516-4519.

Chamley, J. H., G. E. Mark, G. R. Campbell, and G. Burnstock (1972) Sympathetic ganglia in culture. Z. Zellforsch. 135: 287-314.

Collins, F., and A. Dawson (1983) An effect of nerve growth factor on parasympathetic neurite outgrowth. Proc. Natl. Acad. Sci. USA 80: 2091-2094.

D’Ercole, A. J., G. T. Applewhite, and L. E. Underwood (1980) Evidence that somatomedin is synthesized by multiplc tissucs in the fetus. Dev. Biol. 75: 315-328.

Dunn, O. J., and V. A. Clark (1974) Applied Statistics: Analysis of Variance and Regression, Wiley, New York.

Goodner, C. J., and M. A. Berrie (1977) The failure of rat hypothalamic tissues to take up labeled insulin in vivo and to respond to insulin in vitro. Endocrinology 101: 605-612.

Gundersen, R. W., and J. N. Barrett (1980) Characterization of the turning response of dorsal root neurites towards nerve growth factor. J. Cell Biol. 87: 546-554.

Havrankova, J., J. Roth, and M. Brownstein (1978a) Insulin receptors are widely distributed in the central nervous system of the rat. Nature 272: 827-829.

Havrankova, J., D. Schmechel, J. Roth, and M. Brownstein (1978b) Identification of insulin in rat brain. Proc. Natl. Acad. Sci. USA 75: $5737-5741$.

Ishii, D. N. (1978) Effect of tumor promoters on the response of cultured embryonic chick ganglia to nerve growth factor. Cancer Res. 38: 3886-3893.

Ishii, D. N., and E. M. Shooter (1975) Regulation of nerve growth factor synthesis in mouse submaxillary glands by testosterone. J. Neurochem. 25: 843-851.

Ishii, D. N., E. Recio-Pinto, W. Spinelli, J. E. Mill, and K. H. Sonnenfeld (1985) Neurite formation modulated by nerve growth factor, insulin, and tumor promoter receptors. Int. J. Neurosci. 26: 109-1 27.

Landau, B. R., Y. Takaoka, M. A. Abrams, S. M. Genuth, M. van Houten, B. I. Posner, R. J. White, S. Ohgaku, A. Horvat, and E. Hemmelgarn (1983) Binding of insulin by monkey and pig hypothalamus. Diabetes 32: 284-292.

Levi-Montalcini, R. (1964) The nerve growth factor: Its mode of action on sensory and sympathetic nerve cells. Harvey Lect. $60: 217-259$.

Levi-Montalcini, R., and P. U. Angeletti (1968) Nerve growth factor. Physiol. Rev. 48: 534-569.

Mains, R. E., and P. H. Patterson (1973) Primary cultures of dissociated sympathetic neurons. I. Establishment of long-term growth in culture and studies of differentiated properties. J. Cell Biol. 59: 329 345.

Manthorpe, M., E. Engvall, E. Ruoslahti, F. M. Longo, G. E. Davis, and $S$. Varon (1983) Laminin promotes neuritic regeneration from cultured peripheral and central neurons. J. Cell Biol. 97: 1882-1890.

Menesini Chen, M. G., J. S. Chen, and R. Levi-Montalcini (1978) Sympathetic nerve fibers ingrowth in the central nervous system of neonatal rodent upon intracerebral NGF injection. Arch. Ital. Biol. 116: 53-84.

Mill, J. F., M. V. Chao, and D. N. Ishii (1985) Insulin, insulinlike growth factor-II, and nerve growth factor effects on tubulin mRNA levels and neurite formation. Proc. Natl. Acad. Sci. USA 82: 71267130.

Mobley, W. C., A. C. Server, D. N. Ishii, R. J. Riopelle, and E. M. Shooter (1977) Nerve growth factor. N. Engl. J. Med. 297: 10961104 (Part I), 1149-1158 (Part II), and 1211-1218 (Part III).

Moses, A. C., S. P. Nissley, P. A. Short, M. M. Rechler, and J. M. Podskalny (1980) Purification and characterization of multiplication-stimulating activity. Insulin-like growth factors purified from rat liver cell conditioned medium. Eur. J. Biochem. 103: 387-400.

Murphy, R. A., R. H. Singer, J. D. Saide, N. J. Pantazi, M. H. Blanchard, K. S. Byron, B. G. W. Arnason, and M. Young. (1977) Synthesis and secretion of a high molecular weight form of nerve growth factor by skeletal muscle cells in culture. Proc. Natl. Acad. Sci. USA 74 4496-4500.

Pacold, S. T., and W. G. Blackard (1979) Central nervous system insulin receptors in normal and diabetic rats. Endocrinology 105 . $1452-1457$

Phillip, M. E., and R. V. Coxon (1976) Effect of insulin and phenobarbital on uptake of 2-deoxyglucose by brain slices and hemidiaphragms. J. Neurochem. 27: 643-645.

Posner, B. I., P. A. Kelly, R. P. C. Shiu, and H. G. Friesen (1974) Studies of insulin, growth hormone and prolactin binding: Tissue distribution, species variation and characterization. Endocrinology 95: 521-531.

Raizada, M. K., J. W. Yang, and R. E. Fellows (1980) Binding of ${ }^{125} \mathrm{I}-$ insulin to specific receptors and stimulation of nucleotide incorporation in cells cultured from rat brain. Brain Res. 200: 389-400.

Raizada, M. K., J. F. Stamler, J. T. Quinlan, S. Landas, and M. I. Phillips (1982) Identification of insulin receptor-containing cells in primary cultures of rat brain. Cell. Mol. Neurobiol. 2: 47-52.

Rechler, M. M., M. Kasuga, N. Sasaki, M. A. de Vroede, J. A. Romanus, and S. P. Nissley (1983) Properties of insulin-like growth factor receptor subtypes. In Insulin-like Growth Factors/Somatomedins: Basic 
Chemistry, Biology, and Clinical Importance, E. M. Spencer, ed., pp. 459-490, de Gruyter, New York.

Recio-Pinto, E., and D. N. Ishii (1984) Effects of insulin, insulin-like growth factor-II and nerve growth factor on neurite outgrowth in cultured human neuroblastoma cells. Brain Res. 302: 323-334.

Recio-Pinto, E., F. F. Lang, and D. N. Ishii (1984) Insulin and insulinlike growth factor-II permit nerve growth factor binding and the neurite formation response in cultured human neuroblastoma cells. Proc. Natl. Acad. Sci. USA 81: 2562-2566.

Rinderknecht, E., and R. E. Humbel (1976) Polypeptides with nonsuppressible insulin-like and cell growth promoting activities in human serum: Isolation, chemical characterization, and some biological properties of forms I and II. Proc. Natl. Acad. Sci. USA 73: 23652369.

Rinderknecht, E., and R. E. Humbel (1978) Primary structure of human insulin-like growth factor-II. Fed. Eur. Biochem. Soc. Lett. 89: 283-286.

Roger, L. J., and R. E. Fellows (1980) Stimulation of ornithine decarboxylase activity by insulin in developing rat brain. Endocrinology 106: 619-625.

Scott, B. S., V. E. Engelberg, and K. C. Fisher (1969) Morphological and electrophysiological characteristics of dissociated chick embryonic spinal ganglion cells in culture. Exp. Neurol. 23: 230-248.

Snyder, E. Y., and S. U. Kim (1980) Insulin: Is it a nerve survival factor? Brain Res. 196: 565-571.

Soares, M. C., D. N. Ishii, and A. Efstratiadis (1985) Developmental and tissue-specific expression of a family of transcripts related to rat insulin-like growth factor II mRNA. Nucleic Acids Res. 13: 11191134.

Sonnenfeld, K. H., and D. N. Ishii (1982) Nerve growth factor effects and receptors in cultured human neuroblastoma cell lines. J. Neurosci. Res. 8: 375-391.

Spinelli, W., and D. N. Ishii (1983) Tumor promoter receptors regulating neurite formation in cultured human neuroblastoma cells. Cancer Res. 43: 4119-4125.

Spinelli, W., K. II. Sonnenfeld, and D. N. Ishii (1982) Effects of phorbol ester tumor promotors and nerve growth factor on neurite outgrowth in cultured human neuroblastoma cells. Cancer Res. 42: $5067-5073$.

Varon, S., and P. Raiborn (1972) Dissociation, fractionation, and culture of chick embryo sympathetic ganglionic cells. J. Neurocytol. 1: $211-221$

Wood, P. M., and R. P. Bunge (1975) Evidence that sensory axons are mitogenic for Schwann cells. Nature 256: 662-664.

Young, M., J. Oger, M. H. Blanchard, H. Asdourian, H. Amos, and B. G. W. Arnason (1975) Secretion of nerve growth factor by primary chick fibroblast cultures. Science 187: 361-362.

Zapf, J., E. Schoenle, and E. R. Froesch (1978) Insulin-like growth factors I and II. Some biological actions and receptor binding charactcristics of two purified constituents of nonsuppressible insulin-like activity of human serum. Eur. J. Biochem. 87: 285-296. 